\title{
Inside the guts of wood-eating catfishes: can they digest wood?
}

\author{
Donovan P. German
}

Received: 27 March 2009 / Revised: 8 June 2009 / Accepted: 12 June 2009 / Published online: 27 June 2009

(C) The Author(s) 2009. This article is published with open access at Springerlink.com

\begin{abstract}
To better understand the structure and function of the gastrointestinal (GI) tracts of wood-eating catfishes, the gross morphology, length, and microvilli surface area (MVSA) of the intestines of wild-caught Panaque nocturnus, P. cf. nigrolineatus "Marañon", and Hypostomus pyrineusi were measured, and contrasted against these same metrics of a closely related detritivore, Pterygoplichthys disjunctivus. All four species had anatomically unspecialized intestines with no kinks, valves, or ceca of any kind. The wood-eating catfishes had body size-corrected intestinal lengths that were $35 \%$ shorter than the detritivore. The MVSA of all four species decreased distally in the intestine, indicating that nutrient absorption preferentially takes place in the proximal and mid-intestine, consistent with digestive enzyme activity and luminal carbohydrate profiles for these same species. Wild-caught Pt. disjunctivus, and $P$. nigrolineatus obtained via the aquarium trade, poorly digested wood cellulose ( $<33 \%$ digestibility) in laboratory feeding trials, lost weight when consuming wood, and passed stained wood through their digestive tracts in less
\end{abstract}

Communicated by I. D. Hume.

Electronic supplementary material The online version of this article (doi:10.1007/s00360-009-0381-1) contains supplementary material, which is available to authorized users.

D. P. German

Department of Zoology, University of Florida,

Gainesville, FL, USA

D. P. German $(\square)$

Department of Ecology and Evolutionary Biology,

University of California, Irvine, CA 92697, USA

e-mail:dgerman@uci.edu than $4 \mathrm{~h}$. Furthermore, no selective retention of small particles was observed in either species in any region of the gut. Collectively, these results corroborate digestive enzyme activity profiles and gastrointestinal fermentation levels in the fishes' GI tracts, suggesting that the wood-eating catfishes are not true xylivores such as beavers and termites, but rather, are detritivores like so many other fishes from the family Loricariidae.

\section{Keywords Digestion $\cdot$ Xylivory $\cdot$ Nutrition}

\section{Introduction}

Of all the photosynthetic organisms on the planet, woody plants produce more cellulose on a proportional basis than any group of herbaceous plants or algae; $90 \%$ of a tree's biomass is made of cell-wall components, primarily cellulose, embedded in a matrix of indigestible lignin (Karasov and Martínez del Rio 2007). Given the recalcitrance of cellulose and lignin to digestion, wood is, therefore, a difficult resource for an animal to consume and digest. Hence, few animals target wood as food and are considered "xylivorous". The reliance on wood for food has traditionally been limited to a few insect families (Prins and Kreulen 1991), one mollusc family (Xu and Distel 2004), and two mammalian lineages (Vispo and Hume 1995; Felicetti et al. 2000). Recently, several species of Amazonian catfishes in the genera Panaque (Schaefer and Stewart 1993) and Hypostomus (Armbruster 2003, 2004) were described as xylivorous, with enlarged, spoon-shaped teeth for gouging wood (Nelson et al. 1999), and wood composing the only "macroscopic material" in the fishes intestines (Schaefer and Stewart 1993). It remains unknown, however, whether these fishes can actually digest wood and subsist on it. 
The mechanisms of digestion in many xylivorous animals have been described, at least on a basic level; most use endosymbiotic microorganisms to digest cellulose (Prins and Kreulen 1991; Vispo and Hume 1995; Felicetti et al. 2000; Xu and Distel 2004). For example, beavers and porcupines possess expanded hindgut ceca in which microorganisms reside and digest cellulose and other refractory polysaccharides using fermentative pathways (Vispo and Hume 1995). These microorganisms release byproducts of fermentation, short chain fatty acids (SCFAs; e.g., acetate), which the host animal then absorbs and uses to generate ATP (Bergman 1990; Stevens and Hume 1998; Karasov and Martínez del Rio 2007). One would, therefore, have the a priori expectation that, as vertebrates, xylivorous catfishes would function similarly to beavers and porcupines with a reliance on endosymbiotic fermentation to digest wood. However, German and Bittong (2009) found that wood-eating and detritivorous catfishes possess low cellulolytic activities, low levels of SCFAs in their GI tracts, and are equipped to digest soluble components (e.g., $\alpha$ - and $\beta$-glucosides) of detritus rather than refractory polysaccharides.

The family to which the wood-eating catfishes belong, the Loricariidae, is composed of many species (680 described taxa in 80 genera; Armbruster 2004) that consume animal, plant, and detrital material from the benthos (Delariva and Agostinho 2001; Pouilly et al. 2003; de Melo et al. 2004; Novakowski et al. 2008; Salvador et al. 2008; German and Bittong 2009). Wood-eating, however, has evolved twice in the family, as species in the genera Hypostomus (Armbruster 2003) and Panaque (Schaefer and Stewart 1993) are considered xylivorous (German and Bittong 2009). Given that many loricariid catfishes consume amorphous detritus (Araujo-Lima et al. 1986; Delariva and Agostinho 2001; Pouilly et al. 2003; de Melo et al. 2004; Novakowski et al. 2008), how different are the wood-eating catfishes from other detritivorous loricariid catfishes? Do xylivorous catfishes possess specializations of their GI tracts, similar to beavers and porcupines, allowing them to harbor endosymbionts and digest wood, or are these woodeating fishes more similar to other loricariid catfishes?

In this study, I investigated the GI tract morphology and function of the same four xylivorous and detritivorous catfish species as those studied by German and Bittong (2009): two species from the genus Panaque (P. nocturnus Schaeffer and Stewart 1993, and an undescribed species $P$. $c f$. nigrolineatus "Marañon"; J. Armbruster, pers. comm.), representing the two clades of this genus, one species of Hypostomus (H. pyrineusi Ribeiro 1920) representing the other clade of xylivorous catfishes, and the detritivorous Pterygoplichthys disjunctivus Weber 1991. This study, therefore, included both clades of wood-eating catfishes, and a less-derived detritivore from the same family (Armbruster 2004; German and Bittong 2009), allowing for comparison of GI tract morphology and function among closely related species with different diets.

This investigation had six components. First, I examined the intestinal contents of the fishes to determine their diets-do wood-eating catfishes only consume wood, as has been proposed (Schaefer and Stewart 1993; Nelson et al. 1999), or do they also consume other food items? Second, I examined the gross morphology of the fishes' GI tracts to observe whether they have kinks, valves, or ceca that might slow the flow of digesta, thereby allowing endosymbiotic microbes to take refuge in that part of the GI tract (Pryor and Bjorndal 2005; Pryor et al. 2006). Third, I measured the length of the fishes' GI tracts, as gut length can provide insight into a fishes' feeding ecology and digestive strategy (Kramer and Bryant 1995; Elliott and Bellwood 2003; German and Horn 2006; German et al. 2009). Fourth, I examined the gut ultrastructure of the fish with histology (light microscopy), scanning electron microscopy (SEM), and transmission electron microscopy (TEM), and quantitatively determined the surface area of their intestines. The intestinal surface area can allow one to discern where in the GI tract nutrients are most readily absorbed (Frierson and Foltz 1992; Horn et al. 2006). If the loricariids operate as hindgut fermenters, they should have increased absorptive capacity in their hindgut. Fifth, I used the SEM and TEM micrographs to observe where microbes are most densely populated in the fishes' GI tracts. And sixth, I performed two types of feeding trials to determine the extent to which Panaque and Pterygoplichthys digest wood fiber, how quickly wood passes through their guts, and whether there is selective retention of particles (large or small) anywhere along the digestive tract. Overall, this study was designed to examine, on multiple levels, the capabilities of these fishes to harbor endosymbionts and digest wood, which I hypothesized they could.

\section{Materials and methods}

Fish collection

Thirteen adult individuals each of Panaque $c f$. nigrolineatus "Marañon" and P. nocturnus, and two adult individuals of $H$. pyrineusi were captured by seine and a backpack electroshocker from the upper Río Marañon in northern Peru $\left(4^{\circ} 58.957^{\prime} \mathrm{S}, 77^{\circ} 85.283^{\prime} \mathrm{W}\right)$ in August 2006. Nineteen individuals of Pt. disjunctivus were captured by hand while snorkeling from the Wekiva Springs complex in north central Florida $\left(28^{\circ} 41.321^{\prime} \mathrm{N}, 81^{\circ} 23.464^{\prime} \mathrm{W}\right)$ in March 2006. This latter population has been living in Florida for nearly two decades (Nico 2005; Nico et al. 2009). Upon capture, fishes were placed in coolers of aerated river water and held until euthanized (not more than $2 \mathrm{~h}$ ). Fishes were 
euthanized in buffered water containing $1 \mathrm{~g} \mathrm{~L}^{-1}$ tricaine methanesulfonate (MS-222, Argent Chemicals Laboratory, Inc., Redmond, WA, USA), measured [standard length (SL) $\pm 1 \mathrm{~mm}]$, and dissected on a chilled $\left(\sim 4^{\circ} \mathrm{C}\right)$ cutting board. Guts were removed by cutting at the esophagus and at the anus and processed in a manner appropriate for specific analyses (see below).

\section{Gut morphology and length}

Guts from 11 P. cf. nigrolineatus "Marañon", 11 P. nocturnus, and 17 Pt. disjunctivus were removed from the fish, uncoiled, and the intestinal length measured as the distance from the pyloric sphincter to the distal-most end of the intestine. These guts were then immediately frozen and saved for gut content analyses. Gut content analyses were performed following the microscopic techniques described by German et al. (2009).

The measured intestines were used to calculate three digestive-somatic indices commonly used in studies of fish feeding ecology (German and Horn 2006): relative intestinal length $(\mathrm{RIL}=$ intestinal length/SL); intestinal length as a function of snout-vent length (IL/SVL = intestinal length/ snout-vent length), where snout-vent length is the measurement on the ventral surface from the tip of head to the anus; and Zihler's index [Zihler 1982; ZI = intestinal length/ $\left(10 \times\right.$ body mass $\left.\left.^{1 / 3}\right)\right]$, which relates intestinal length to body mass. These indices allow for the comparison of gut length among fishes with different diets while controlling for differences in body size (Kramer and Bryant 1995; German and Horn 2006).

\section{Histological, TEM, and SEM analyses}

Upon removal from the body, the digestive tracts of two individuals of each species were immediately placed in ice-cold Trump's fixative ( $4 \%$ formaldehyde, $1 \%$ glutaraldehyde, in $10 \mathrm{mM}$ monobasic sodium phosphate and $6.75 \mathrm{mM}$ sodium hydroxide; McDowell and Trump 1976), pH 7.5, to prevent any degradation of the gut ultrastructure. The guts were uncoiled while submerged in the fixative, the length of the intestine was measured [IL $(\mathrm{mm})]$, and six 1-mm sections were excised from each of the proximal and mid-intestines, and eight sections were taken from the distal intestine (Frierson and Foltz 1992). The tissue sections were placed in their own individual vials containing fresh Trump's fixative and kept cool $\left(\sim 4-10^{\circ} \mathrm{C}\right)$ for transport back to the University of Florida. Three of the sections were designated for analysis with TEM, whereas the other three were designated for use in histological analyses and light microscopy. The remaining two sections from the distal intestine were used for SEM analyses.
Upon arrival at the laboratory (approximately 3 weeks), the tissues were removed from the fixative and rinsed in $0.1 \mathrm{M}$ phosphate buffered saline (PBS), $\mathrm{pH} 7.5$, for $3 \times$ $20 \mathrm{~min}$, and a final rinse overnight at $4{ }^{\circ} \mathrm{C}$. Following rinsing in PBS, the tissues designated for histological analyses were rinsed for $40 \mathrm{~min}$ in running DI water, and dehydrated in a graded ethanol series. The samples were then impregnated in two changes of Citrisolve for $20 \mathrm{~min}$ each, and infiltrated in four changes of paraffin (TissuePrep 2, Fisher Scientific, Fair Lawn, NJ, USA) for 30, 45, 60, and $60 \mathrm{~min}$ in a vacuum oven at $60^{\circ} \mathrm{C}$. The tissues were then embedded in paraffin at $57^{\circ} \mathrm{C}$ and the blocks stored at room temperature before use. Intestinal tissues were serially sectioned at $7 \mu \mathrm{m}$, stained in a modified Masson's trichrome (Presnell and Schreibman 1997), and photographed at $40 \times, 60 \times$, and $120 \times$ with a Hitachi KP-D50 digital camera attached to an Olympus BX60 bright-field light microscope. Images $(n=5$ per intestinal region, per individual fish; 30 images per species) were used to qualitatively examine the gut structure of the fish.

Tissue sections designated for TEM were postfixed in $1 \%$ osmium tetroxide for $12 \mathrm{~h}$ at $4^{\circ} \mathrm{C}$, and rinsed in running DI water for $40 \mathrm{~min}$. The tissues were then dehydrated in a graded ethanol series, followed by a graded acetone series at room temperature $\left(22^{\circ} \mathrm{C}\right)$, and embedded in Spurr's resin (Ted Pella Inc., Redding, CA, USA). Blocks were cut into $1-\mu \mathrm{m}$ thick sections using a Reichert-Jung Ultracut-E microtome (Jena, Germany). The sections were stained with $1 \%$ toluidine blue, and examined under a bright-field light microscope (Olympus BX60) to find sections with appropriate intestinal folds (Horn et al. 2006). Ultrathin sections $(70 \mathrm{~nm})$ were then cut with a diamond blade from the same central part of each selected mucosal fold, mounted on honeycomb copper grids (Pelco 8GC 180 or 270, Ted Pella) and stained with $1 \%$ uranyl acetate and $2 \%$ lead citrate. Cross-sections of 4-6 enterocytes with undistorted microvilli were photographed using a transmission electron microscope (H-7000, Hitachi, Japan). Using five images per intestinal region per individual fish (30 images per species), the microvilli surface area (MVSA) per length of the intestinal epithelium for each of the proximal, mid-, and distal intestine was determined following the twodimensional model of Frierson and Foltz (1992) as described by Horn et al. (2006), the only departure being that ImageJ analytical software (Abramoff et al. 2004) was used to take measurements. The TEM micrographs were also used to examine the presence of microbes in different regions of the gut.

The distal intestine sections designated for SEM analyses were dehydrated with a graded ethanol series and hexamethyldisilazine, mounted on aluminum stubs, and sputter-coated with gold palladium. Specimens were examined using a Hitachi S-4000 FE SEM (Hitachi Instruments, San Jose, CA). 
Fiber digestibility

To evaluate whether Pt. disjunctivus and a wood-eating loricariid catfish, $P$. nigrolineatus, could digest wood fiber, I performed a traditional fiber digestibility feeding trial using a total collection method (Galetto and Bellwood 1994). Five individuals of Pt. disjunctivus (mean $\pm \mathrm{SD} ; 221.88 \pm$ $9.83 \mathrm{~mm} \mathrm{SL} ; 214.44 \pm 23.09 \mathrm{~g} \mathrm{BM})$ were collected from Wekiva Springs, FL, in September 2007 and brought back to the University of Florida. Seven individuals of $P$. nigrolineatus $(176.43 \pm 20.73 \mathrm{~mm} \mathrm{SL} ; 227.76 \pm 78.71 \mathrm{~g} \mathrm{BM})$ were obtained from an aquarium wholesaler (5-D Tropical, Tampa, FL) as the fish arrived from Venezuela, where they were captured from their native habitat. Individuals of both species were individually assigned to $75.6-\mathrm{L}$ aquaria equipped with a $2.5 \mathrm{~cm}$ plastic mesh at the bottom, which allowed feces and uneaten food ("orts") to fall through and be undisturbed by the fish. The intake tube of the mechanical filter was covered with $250-\mu \mathrm{m}$ mesh screen to prevent uneaten orts and feces from being sucked into the filter. Every 2 days the fishes were given a new piece $(\sim 100 \mathrm{~g}$, wet weight) of water-logged, degraded water oak (Quercus nigra) wood on which to graze. The fishes were allowed to acclimate to these conditions for at least 1 month prior to the beginning of the experiment.

Each afternoon $(\sim 15: 00)$ during the experimental period (4 weeks duration for P. nigrolineatus, 6 weeks duration for Pt. disjunctivus), the fishes were gently removed from their tanks into an individual bucket containing aquarium water. The plastic mesh was removed from the bottom of the tank, and the feces, which were completely distinguishable from the orts, were siphoned off with a $25 \mathrm{~mL}$ bulb pipette into a weigh boat. Ort debris was siphoned off with a piece of vinyl tubing onto a $250-\mu \mathrm{m}$ mesh screen, from which it was scraped with a razorblade into weigh boats for each tank. The feces and debris were dried at $60^{\circ} \mathrm{C}$ for $24 \mathrm{~h}$, weighed, and stored in sealed glass vials. On a daily basis, the wood pieces provided to each fish were blotted with a paper towel, weighed (wet mass), and a small subsample was scraped off with a razorblade. The wood was then weighed again before being returned to the tank. Daily diet samples, as well as daily feces and ort samples for an individual fish, were combined to obtain a composite sample for each of the diet, feces, and orts across the feeding trial (Bouchard and Bjorndal 2006).

Wood and ort samples were ground to pass through a 1-mm screen in a coffee grinder, and fecal samples were ground with a mortar and pestle. Fecal, ort, and diet samples were analyzed for dry matter, organic matter, neutral detergent fiber (NDF), acid detergent fiber (ADF), lignin + cutin, and \%N (Bouchard and Bjorndal 2006). Ort analysis allowed us to examine whether the fishes fed selectively on "more nutritious" portions of the wood.
Ash (mineral) content was determined by drying subsamples overnight at $105^{\circ} \mathrm{C}$ and then combusting them at $550^{\circ} \mathrm{C}$ for $4 \mathrm{~h}$. The difference between the sample masses dried at $105^{\circ} \mathrm{C}$ and combusted at $550^{\circ} \mathrm{C}$ represents the organic matter component of the sample. NDF and ADF were determined by sequentially refluxing samples with neutral detergent and acid detergent solutions (Goering and Van Soest 1970) in an Ankom ${ }^{200}$ Fiber Analyzer according to the guidelines supplied with the equipment (Ankom Technology 1998, 1999). NDF represents the cell-wall component of the wood (cellulose, hemicellulose, and lignin), and ADF represents the ligno-cellulose component. The actual lignin + cutin portion was determined by refluxing the samples in $72 \%$ sulfuric acid for $3 \mathrm{~h}$ at room temperature $\left(24^{\circ} \mathrm{C}\right.$; Moran and Bjorndal 2007). The $\mathrm{N}$ content of the samples was determined using a Carlo Erba elemental analyzer.

Daily consumption rates, on a dry matter basis (and later converted to organic matter), were calculated from a regression of wet weight versus dry weight of water oak wood pieces minus the mass of orts $\left(r^{2}=0.99\right)$. Thus, we were able to calculate digestibility coefficients based on total intake and fecal output. Digestibility was determined using the equation (intake-feces)/intake, where intake is total grams of organic matter consumed during the trial and feces is grams of organic matter in the feces produced during the trial. It should be noted that the organic matter digestibilities are "apparent digestibilities" (because the fishes contribute organic waste, such as sloughed intestinal cells, to the feces) and the fiber digestibilities (NDF, ADF, lignin) represent "true digestibilities" (because the fishes contribute no fiber to the feces).

Transit time of wood in the digestive tract

One of the most important elements in studies of digestion is how long food is held in the digestive tract, as this provides key information into the strategy an animal takes to digest a meal (Karasov and Martínez del Rio 2007). At the conclusion of the fiber digestibility experiment, $P$. nigrolineatus and Pt. disjunctivus were fed water oak wood that had been stained red with carmine dye (Fris and Horn 1993). The wood pieces were submerged in a $2 \%$ carmine dye solution for at least 1 month. They were then presteeped under agitation $(3 \times 10 \mathrm{~min})$ in aquarium water to remove loose dye particles and ensure that only fully stained wood was offered to the fish. Wood pieces $(\sim 100 \mathrm{~g})$ were placed in tanks as described in "Fiber digestibility" only the tanks were without the plastic mesh at the bottom. Four hours after the commencement of feeding, two individuals were euthanized in MS-222 as described above. After this initial 4-h feeding period, the stained wood was replaced with non-stained wood in the tanks of the remaining 
fishes to allow for the tracking of the stained wood (i.e., the pulse) through the gut. Two additional fishes were taken and euthanized at 6 and $8 \mathrm{~h}$, and the remaining fishes at 18 -h post feeding. At each sampling interval, the presence or absence of red-stained feces in the aquaria was noted to determine minimum retention time of wood in the gut (Fris and Horn 1993).

At each sampling interval, the fishes were dissected on a sterile cutting board, and the gut was removed, uncoiled, measured, and photographed. The red dye on the wood was visible in the gut contents of $P$. nigrolineatus, but not in $P t$. disjunctivus, mainly because the latter species produces an inordinate amount of bile that is nearly black in color. Thus, I was unable to address particle retention in Pt. disjunctivus and only have the amount of time taken for red feces to appear in the aquaria for this species. In P. nigrolineatus, the intestine was divided into three sections of equal length and the proximal-most location of the red-stained wood in the gut was noted at each sampling interval. The intestinal contents were squeezed from each intestinal section with forceps and the blunt side of a razor blade into sterile centrifuge vials and frozen at $-80^{\circ} \mathrm{C}$ until analyzed ( $\sim 1$ month). When analyzed, the samples were defrosted, and the contents were wet sieved (Vispo and Hume 1995) using mesh sizes ranging from 0.25 to $1.5 \mathrm{~mm}$. Following the sieving, the contents were dried at $60^{\circ} \mathrm{C}$ for $24 \mathrm{~h}$, the samples of the various particle size classes were weighed, and the proportion of each particle size class was determined. This experiment was repeated 1 month later with an additional seven $P$. nigrolineatus obtained from the same aquarium wholesaler.

\section{Statistical analyses}

Prior to all significance tests, a Levene's test for equal variance was performed and residual versus fits plots were examined to ensure the appropriateness of the data for parametric analyses. All tests were run using SPSS (version 11) and Minitab (version 12) statistical software packages. The various digestive-somatic indices were compared among species with ANCOVA, using body mass as a covariate, followed by a Tukey's HSD with a family error rate of $P=0.05$. Intraspecific comparisons of MVSA among gut regions were made with ANOVA followed by a Tukey's HSD with a family error rate of $P=0.05$.

\section{Results}

Gut size and diet

The digestive tracts of $P . c f$. nigrolineatus "Marañon", $P$. nocturnus, Pt. disjunctivus, and $H$. pyrineusi were very similar in morphology. All four species have extremely long, thin-walled intestines that exceed $10 \times$ the body length of the animal (Table 1; Fig. 1), but Pt. disjunctivus possesses a significantly longer gut than either of the Panaque species (Table 1). I was only able to measure the gut length of two individuals of $H$. pyrinuesi, and thus, they were not included in the statistical analyses. But, the digestive-somatic indices in this species $(\mathrm{RIL}=11.85 ; \mathrm{IL} / \mathrm{SVL}=$ 20.13; ZI $=40.03$ ) were more similar to the species of Panaque than to Pt. disjunctivus.

The gut contents of $P$. $c f$. nigrolineatus "Marañon" were dominated by wood (75\%), amorphous detritus (17\%), and diatoms (6\%), with algae and sediment each composing $1 \%$ of the total (Fig. 2). Similarly, P. nocturnus possessed wood $(70 \%)$, amorphous detritus (18\%), diatoms (8\%), algae (2\%), and sediment (2\%) in their intestines. Pt. disjunctivus displayed a different distribution of dietary items with detritus composing $40 \%$ of its diet, followed by diatoms $(23 \%)$, algae $(22 \%)$, sediment $(10 \%)$, and animal material (5\%; Fig. 2). SEM micrographs showed debris and diatoms in the distal intestines of these three same species.

Table 1 Interspecific comparisons of body mass (BM), relative intestinal length (RIL), intestinal length as a function of snout-vent length (IL/SVL), and Zihler's index (ZI) in three species of loricariid catfishes

\begin{tabular}{|c|c|c|c|c|c|c|}
\hline Species $(N)$ & Diet & $\mathrm{SL}(\mathrm{mm})$ & $\mathrm{BM}(\mathrm{g})$ & RIL & IL/SVL & ZI \\
\hline $\begin{array}{l}\text { P. cf. nigrolineatus } \\
\text { "Marañon" (11) }\end{array}$ & $\mathrm{W}$ & $87.65 \pm 9.99$ & $29.59 \pm 8.83^{\mathrm{a}}$ & $11.56 \pm 0.50^{\mathrm{a}}$ & $18.97 \pm 0.96^{\mathrm{a}}$ & $36.71 \pm 1.58^{\mathrm{a}}$ \\
\hline P. nocturnus (11) & $\mathrm{W}$ & $102.24 \pm 3.62$ & $32.69 \pm 3.79^{\mathrm{a}}$ & $11.47 \pm 0.41^{\mathrm{a}}$ & $18.44 \pm 0.62^{\mathrm{a}}$ & $37.53 \pm 1.28^{\mathrm{a}}$ \\
\hline Pt. disjunctivus (17) & AD & $203.94 \pm 8.23$ & $196.83 \pm 23.01^{\mathrm{b}}$ & $17.24 \pm 0.55^{\mathrm{b}}$ & $27.19 \pm 0.92^{\mathrm{b}}$ & $61.93 \pm 1.90^{\mathrm{b}}$ \\
\hline Species & & & $F_{2,44}=28.03, P<0.001$ & $F_{2,44}=55.58, P<0.001$ & $F_{2,44}=12.58, P<0.001$ & $F_{2,44}=28.01, P<0.001$ \\
\hline Body mass & & & - & $F_{1,41}=1.42, P=0.240$ & $F_{1,41}=0.72, P=0.401$ & $F_{1,41}=1.21, P=0.279$ \\
\hline
\end{tabular}

Values are mean $( \pm$ SEM). Interspecific comparisons of BM were made with ANOVA followed by a Tukey's HSD with a family error rate of $P=0.05$. Interspecific comparisons of gut dimension parameters were analyzed with ANCOVA (using body mass as a covariate) and Tukey's HSD with a family error rate of $P=0.05$. Values for a parameter that share a superscript letter are not significantly different. Standard length (SL) is shown, but no comparisons were made among the species for body length

$W$ wood, $A D$ algae and detritus 


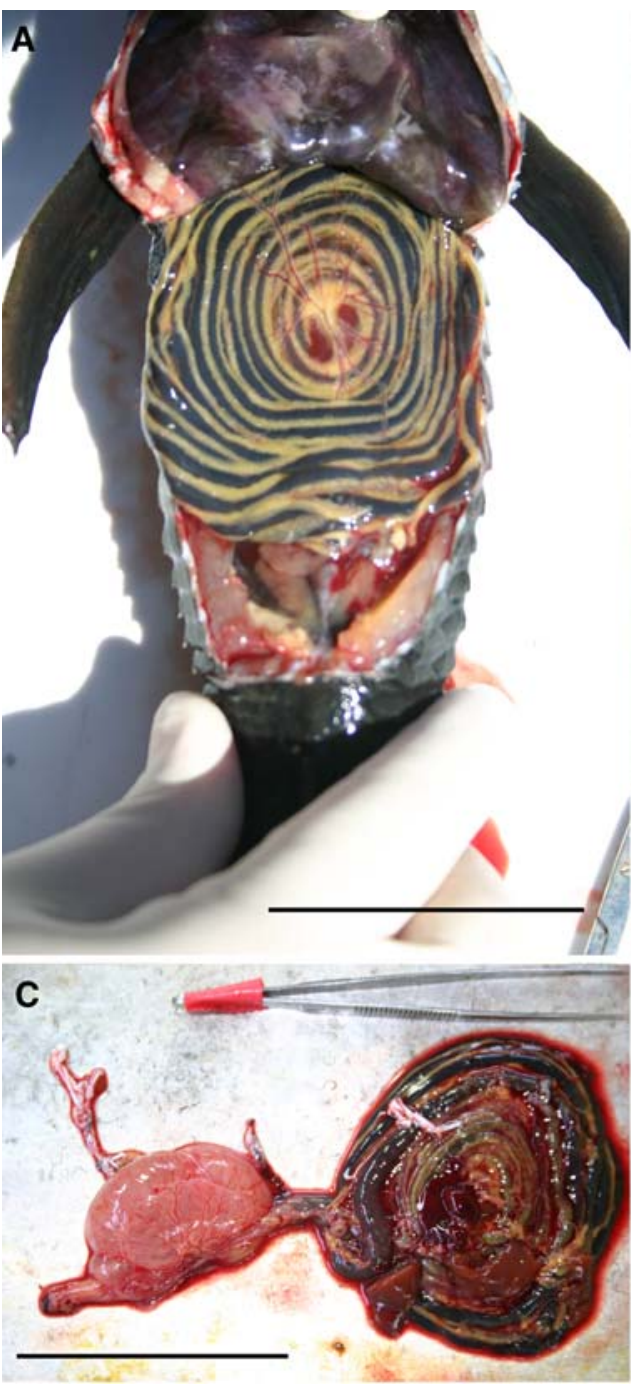

Fig. 1 Photographs of the digestive tract of Pterygoplichthys disjunctivus: coiled within the body cavity (a scale bar $=75 \mathrm{~mm}$ ); uncoiled beneath the body of the fish, with fatty deposits around the intestine

Conglomerations of microbes (e.g., as in bullfrog tadpole hindguts; Pryor and Bjorndal 2005) were noticeably absent in the distal intestines of the loricariid catfishes.

\section{Histology and MVSA analyses}

The digestive tracts of the loricariid catfish species were similar on the histological and TEM micrograph levels (Fig. 3). All four species showed the same pattern of decreasing height of intestinal folds, and decreasing microvilli length and density distally in the intestine. No conglomerations of microbes were observed anywhere along the intestines of the four species in the TEM micrographs (Fig. 3).

The three xylivorous species significantly decreased the MVSA distally in their intestines $(P$. cf. nigrolineatus "Marañon": ANOVA $F_{2,5}=15.91, P=0.029 ; P$. nocturnus: ANOVA $F_{2,5}=60.28, P=0.004 ; H$. pyrineusi: ANOVA (b scale bar $=150 \mathrm{~mm}$ ); and, freshly removed from the body, coiled (c scale bar $=75 \mathrm{~mm}$ )

$\left.F_{2,5}=12.74, P=0.034\right)$, whereas Pt. disjunctivus did not (ANOVA $F_{2,5}=0.57, P=0.593$; Fig. 4 ).

Fiber digestibility and gut transit

The wood I offered to the fishes in the laboratory was almost entirely organic matter (97\% on a dry matter basis), and moderately rich in ligno-cellulose $(\sim 60 \%$; Table 2$)$. Because I observed no feeding selectivity on specific types of wood in the wild in Peru, degraded wood of any riparian tree seemed appropriate for this part of the study. Neither $P$. nigrolineatus nor Pt. disjunctivus readily assimilated large proportions of the organic matter, or of the fiber types of the water oak (Table 3). The digestibilities for NDF and ADF each contributed approximately the same amount of overall organic matter digestion (Table 3). For example, $22 \%$ digestibility of NDF that composes $78 \%$ of the total 

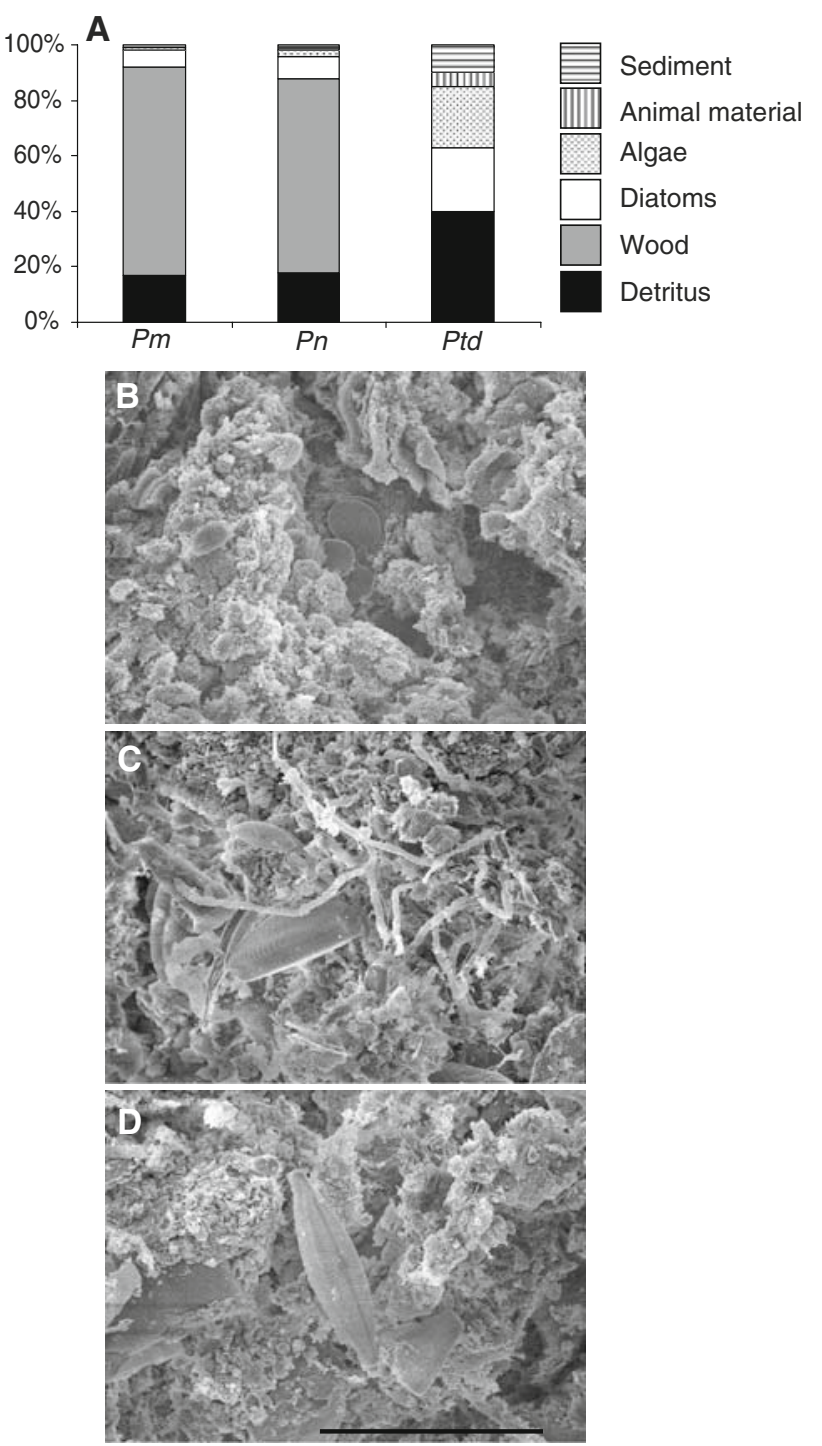

Fig. 2 Gut contents of three loricariid catfish species. a Proportions of detrital, wood, diatomaceous, algal, animal, and sediment material in the gut contents of Panaque cf. nigrolineatus "Marañon" $(P m), P$. nocturnus $(P n)$, and Pterygoplichthys disjunctivus (Ptd). b-d Scanning electron microscope images of the distal intestine gut contents of these same three species (in the same order) showing debris and diatoms among the digesta $($ scale bar $=20 \mu \mathrm{m})$

organic matter equals a total digestibility of $17 \%$. Similarly, $24 \%$ digestibility of ADF that composes $61 \%$ of the total equals a total digestibility of $15 \%$. Thus, most of the fiber digestibility can be accounted for via ADF and lignin digestion. Furthermore, the lignin:cellulose ratio (Abril and Bucher 2002) of the feces $(0.90 \pm 0.16)$ was not significantly greater than the lignin:cellulose ratio of the wood $(0.81 \pm 0.08 ; t=0.49, P=0.63, d f=20)$, suggesting that the fishes were unable to assimilate significant amounts of cellulose from the wood diet.

The fishes consumed $2-5 \%$ of their body mass (on a wet weight basis) in wood per day, but were not thriving on it, as $P$. nigrolineatus lost $1.8 \pm 0.15 \%$ of their body mass over the course of the experiment, and Pt. disjunctivus lost $8.4 \pm 0.81 \%$ of their body mass. This stands in contrast to a $41 \%$ mass gain by Pt. disjunctivus on an algal diet in the laboratory (German 2008). Furthermore, P. nigrolineatus and Pt. disjunctivus excreted more nitrogen in their feces than they consumed in the wood (Table 3), and this excretion was significantly greater for Pt. disjunctivus than for $P$. nigrolineatus.

Wood traversed the digestive tracts of the two species quickly, with red-stained wood appearing in feces less than $4 \mathrm{~h}$ after its consumption. Furthermore, there appeared to be no retention of the stained wood along the gut of $P$. nigrolineatus (Fig. 5). The proportion of particles (stained or non-stained) $<250 \mu \mathrm{m}$ in diameter in each region of the intestine at each time interval was as follows (mean \pm SEM; $n=3-4)-4$ h: PI $47.59 \pm 1.66$, MI $25.44 \pm 1.50$, DI $22.53 \pm 2.77 ; 6$ h: PI $44.09 \pm 3.61$, MI $22.33 \pm 2.33$, DI $17.26 \pm 2.66$; 8 h: PI $45.21 \pm 7.74$, MI $28.60 \pm 4.28$, DI $23.31 \pm 3.63 ; 18 \mathrm{~h}$ : DI $19.05 \pm 1.08$ (digesta was only present in the DI at the 18-h interval). Thus, no selective retention of small particles was observed in this study. In addition, the overall analysis of particle size in the guts of $P$. nigrolineatus revealed that small, more digestible particles were not retained anywhere along the gut, with particles $>350 \mu \mathrm{m}$ making up more of the total moving distally along the intestine (Table 4). However, the results could be interpreted to show selective retention of larger particles ( $>350 \mu \mathrm{m}$ in diameter) in the mid- and distal intestine.

\section{Discussion}

The data gathered in this study clearly support the null hypothesis that the "xylivorous" loricariid catfishes do not efficiently digest the fibrous components of wood in their GI tracts. Each of the analyses provided evidence that the fishes do not exhibit specialized gut anatomy for harboring endosymbionts: no kinks, valves, or ceca are present anywhere along their long, narrow intestines; the MVSA decreases distally in the intestine, indicating that most absorption takes place in the proximal and mid-intestine; no conglomerations of microbes were observed in the SEM or TEM micrographs; the fishes pass wood through the gut too quickly $(<4 \mathrm{~h}$ ) for microbial digestion of cellulose; and the fishes do not retain small particles anywhere along their digestive tract. Furthermore, the catfishes were unable to digest wood and thrive on it in the laboratory. Each of these components would be expected to be the opposite in an animal that digests wood via an endosymbiotic community of microbes living in their GI tract. However, loricariid catfishes certainly have interesting digestive tracts (the longest among all fishes measured to date; Horn 1989; 


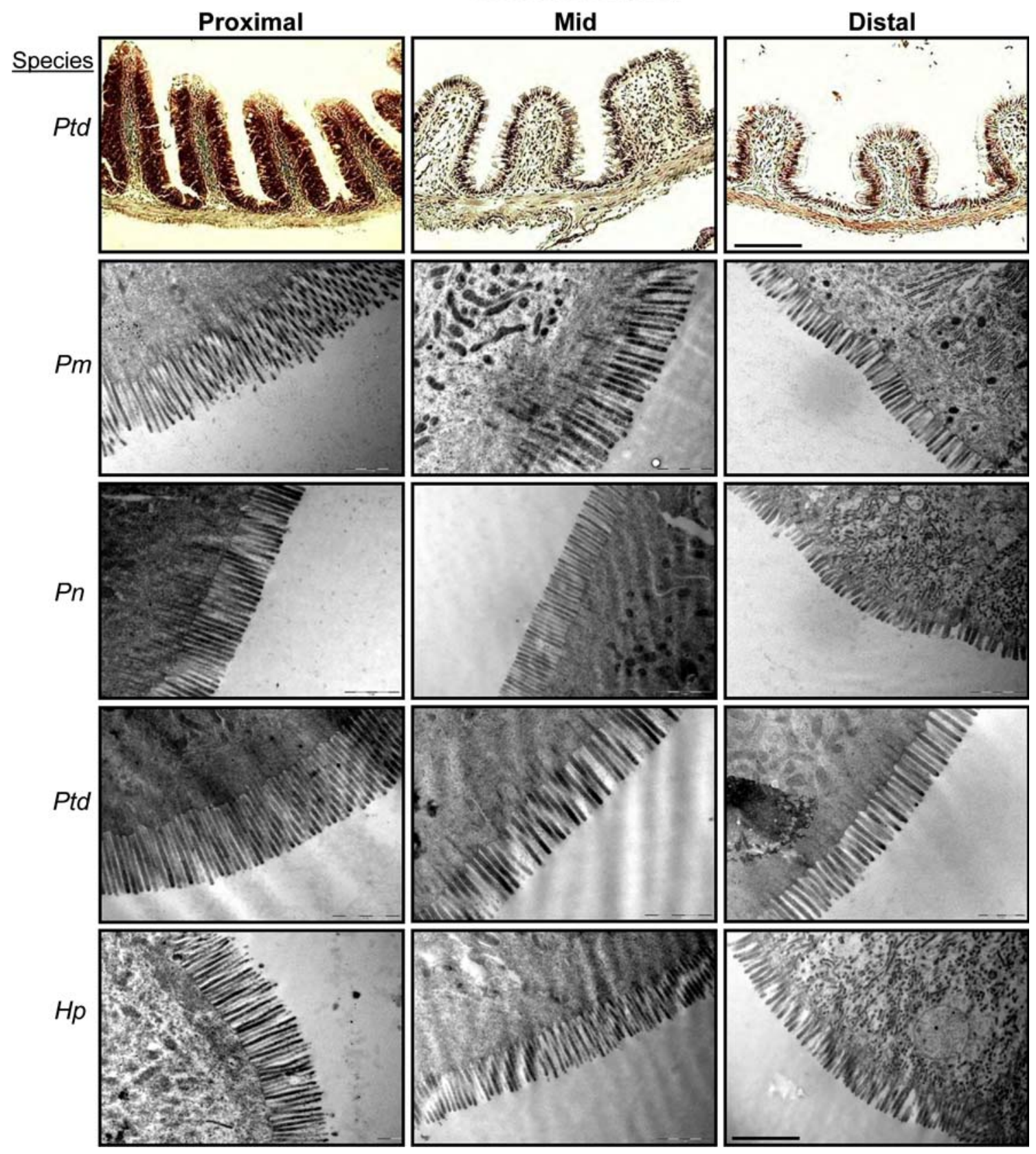

Fig. 3 Histological images and transmission electron microscope (TEM) micrographs of the proximal intestine (PI), mid-intestine (MI), and distal intestine (DI) of Pterygoplichthys disjunctivus (Ptd),

Kramer and Bryant 1995) and subsist on detritus in the wild, which they appear suited to digest (Bowen et al. 1995; German 2009; German et al. 2009).

There has been some debate over the last 15 years as to whether xylivorous catfishes can digest wood. Schaefer and Stewart (1993) suggested that species in the genus Panaque "could be capable of extracting energy from wood" and this assertion has been assumed to be true ever since, especially on the internet and among
Panaque cf. nigrolineatus "Marañon" $(P m), P$. nocturnus $(P n)$, and Hypostomus pyrineusi $(\mathrm{Hp})$. Scale bar for histology $=165 \mu \mathrm{m}$, scale bar for TEM $=1 \mu \mathrm{m}$

aquarium fish enthusiasts. However, the one study published to date examining digestion in species of Panaque and Pterygoplichthys provided only inferential evidence of cellulose digestion (Nelson et al. 1999). The data gathered in the current study and that of German and Bittong (2009) systematically refute that wood-eating species in the genera Panaque or Hypostomus, or the detritivorous Pt. disjunctivus, have the capability to digest and subsist on wood. 


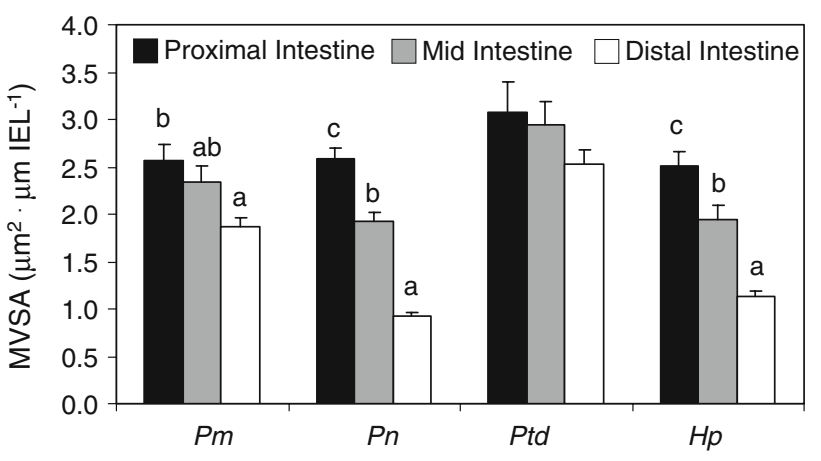

Fig. 4 Microvilli surface area (MVSA, $\mu \mathrm{m}^{2}$ ) per length of intestinal epithelium (IEL, $\mu \mathrm{m})$ in Panaque cf. nigrolineatus "Marañon" $(P m)$, P. nocturnus (Pn), Pterygoplichthys disjunctivus (Ptd), and Hypostomus pyrineusi $(\mathrm{Hp})$. Values are means and error bars represent SEM. Intraspecific comparisons of MVSA among gut regions were made with ANOVA followed by a Tukey's HSD with a family error rate of $P=0.05$. Regional MVSA for a particular species that share a letter are not significantly different. No letters above gut regions (e.g., Pt. disjunctivus) indicate that there are no differences in MVSA among the intestinal regions for that species. Interspecific comparisons among species were not made

Table 2 Nutritional composition of water oak (Quercus nigra) wood consumed by Panaque nigrolineatus and Pterygoplichthys disjunctivus in laboratory feeding trials

\begin{tabular}{lc}
\hline & Percent of total* \\
\hline Organic matter (OM) & $97.19 \pm 0.19$ \\
Nitrogen & $0.13 \pm 0.01$ \\
NDF (total fiber) & $78.10 \pm 0.47$ \\
ADF (ligno-cellulose) & $61.89 \pm 0.55$ \\
Acid detergent lignin & $27.05 \pm 1.46$ \\
\hline
\end{tabular}

Values are mean $( \pm \mathrm{SEM}) . n=11$

* Organic matter is percent of dry matter, whereas the fiber percentages are on an organic matter basis

Two of the key factors contributing to this inability are the lack of specialized gut anatomy and rapid gut transit. The loricariid catfishes examined in this study have long, narrow, anatomically unspecialized intestines, and no conglomerations of microbes were observed in the fishes' guts. However, unlike terrestrial herbivores and xylivores, a specialized gut anatomy is not a prerequisite for fishes to harbor an endosymbiotic community in their GI tracts. Many herbivorous fishes (e.g., Odax pullus and O. cyanomelas) with active endosymbiotic communities and high levels of SCFA production and assimilation (Mountfort et al. 2002) have anatomically unspecialized digestive tracts (Clements and Choat 1995; Clements and Raubenheimer 2006). $O$. pullus and $O$. cyanomelas do, however, possess voluminous guts, and $O$. pullus has relatively long retention of digesta in the alimentary tract (12-20 h), mainly because of low gut contractility (Clements and Rees 1998). This low contractility may be due to the very thin musculature
Table 3 Digestibilities (\%) of various fractions of wood consumed by Panaque nigrolineatus and Pterygoplichthys disjunctivus in laboratory feeding trials

\begin{tabular}{lcc}
\hline & $\begin{array}{l}\text { Panaque } \\
\text { nigrolineatus }\end{array}$ & $\begin{array}{l}\text { Pterygoplichthys } \\
\text { disjunctivus }\end{array}$ \\
\hline Organic matter (OM) & $11.37 \pm 0.89$ & $12.76 \pm 1.52$ \\
Nitrogen & $-114.93 \pm 22.90^{\mathrm{b}}$ & $-397.78 \pm 86.50^{\mathrm{a}}$ \\
NDF (total fiber) & $22.95 \pm 2.40$ & $31.54 \pm 3.56$ \\
ADF (ligno-cellulose) & $23.69 \pm 2.55$ & $32.08 \pm 3.04$ \\
Acid detergent lignin & $36.87 \pm 2.62$ & $32.92 \pm 3.51$
\end{tabular}

Values are mean $( \pm$ SEM). DM and OM digestibilities are "apparent digestibilities" because of endogenous inputs from the fish, whereas digestibilities for NDF, ADF, and lignin are "true digestibilities" because the fishes do not excrete any substances that are considered fibrous. P. nigrolineatus, $n=7 ;$ Pt. disjunctivus, $n=4$. Nitrogen digestibilities were significantly different $(t=4.05, P=0.003$, d.f. $=9)$ between the two species, as indicated with the different superscript letters

surrounding the intestine of this species (Clements and Rees 1998), and also may result in significant amounts of axial mixing of digesta in the gut, an important component of microbially mediated digestion (Horn 1989; Horn and Messer 1992; Karasov and Martínez del Rio 2007). Xylivorous termites have extremely long digesta transit considering their size ( $\sim 24 \mathrm{~h}$; Breznak and Brune 1994), porcupines consuming wood have mean retention times of food in the gut exceeding $34 \mathrm{~h}$ (Felicetti et al. 2000), and beavers selectively retain small particles and fluid in their hindgut ceca (Vispo and Hume 1995). Both long retention time of digesta in the gut and selective retention of small particles allow resident microbes to remain in the GI tract and digest cellulose in these taxa.

The species of Panaque, Pterygoplichthys, and Hyposto$m u s$ investigated in this study have rapid gut transit, and no selective retention of small particles, suggesting more of a unidirectional, "plug-flow" movement of digesta with little axial mixing along the intestine (Penry and Jumars 1987; Horn and Messer 1992; Jumars 2000). Rapid gut transit $(<1 \mathrm{~h})$ has also been observed in another loricariid catfish, Ancistrus triradiatus, consuming periphyton (Hood et al. 2005). Thus, rapid gut transit has been observed in all loricariids examined to date. Furthermore, the peristaltic contractions of the intestine of $P$. nocturnus are strong and continue after the death of the animal (see supplemental video 1). Hence, the combination of long, narrow intestines, rapid gut transit, and strong contractility do not support an active microbial community in the catfishes' digestive tracts. The decreasing intestinal surface area distally in the intestine observed in the catfishes is also consistent with other detritivorous fishes (Frierson and Foltz 1992), which typically rely more on endogenous digestive mechanisms than on microbial endosymbionts (Bowen 


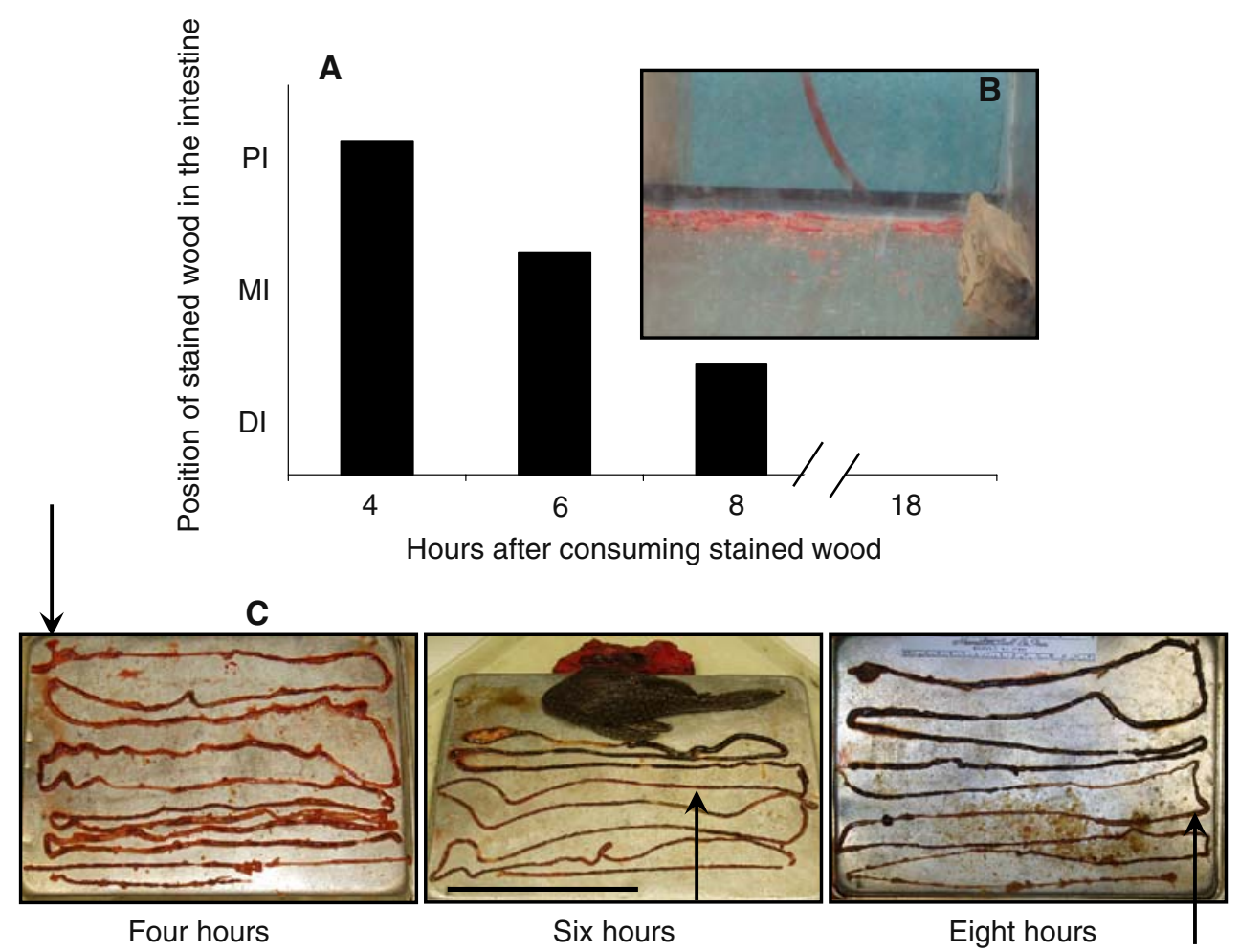

Fig. 5 Position of stained wood in the intestine of Panaque nigrolineatus at different time intervals following its consumption. The fishes were allowed to graze on the wood for $4 \mathrm{~h}$ (pulse), at which time the stained wood was taken away from the fish and replaced with nonstained wood so the fish could continue to feed. Four individual fishes were sacrificed and the position of stained wood in the gut observed at $4,6,8$, and $18 \mathrm{~h}$ following commencement of feeding on the stained wood. a Graphical representation of the proximal-most position of stained wood in the fishes' intestines at different time intervals. b Stained feces present in aquaria at the 4-h interval, indicating gut transit of less than $4 \mathrm{~h}$. $\mathbf{c}$ Photographs of the fishes' intestines at different time intervals showing the red-stained wood in their intestines. The arrows indicate the proximal-most position in the stained wood in the fishes' guts at the time of death (scale bar $=150 \mathrm{~mm})$. No stained wood remained in the intestine at 18 -h post feeding (photo not shown) (color figure online)

Table 4 Particle sizes of intestinal contents presented as the percent of total contents for each of the proximal, mid, and distal intestine of Panaque nigrolineatus

\begin{tabular}{llrrrrr}
\hline Region of intestine & $<250 \mu \mathrm{m}$ & $250-350 \mu \mathrm{m}$ & $351-700 \mu \mathrm{m}$ & $701-1,000 \mu \mathrm{m}$ & $1,001-1,500 \mu \mathrm{m}$ & $\geq 1,501 \mu \mathrm{m}$ \\
\hline Proximal & $44.59 \pm 4.97$ & $10.73 \pm 0.69$ & $18.10 \pm 1.76$ & $9.26 \pm 1.19$ & $8.76 \pm 1.58$ & $8.56 \pm 1.47$ \\
Mid & $25.42 \pm 3.37$ & $13.47 \pm 1.75$ & $24.20 \pm 2.69$ & $10.17 \pm 2.63$ & $13.23 \pm 1.50$ & $13.51 \pm 1.93$ \\
Distal & $23.82 \pm 2.64$ & $8.56 \pm 0.93$ & $30.06 \pm 3.51$ & $10.21 \pm 1.04$ & $13.09 \pm 2.23$ & $14.25 \pm 3.90$ \\
\hline
\end{tabular}

Values are mean \pm SEM. $N=6$ for proximal and mid-intestine, $N=7$ for distal intestine

1984; Smith et al. 1996; Smoot and Findlay 2000; Crossman et al. 2005; German 2009; German and Bittong 2009). Given that Nelson et al. (1999) were only able to isolate aerobic and facultatively anaerobic microbes from the guts of Panaque and Pterygoplichthys, it is probable that these microorganisms are transient and consumed with detritus rather than representing an endosymbiotic community. This does not mean that there are no resident microbes in the guts of the fishes, but any microbes residing in the fishes' GI tracts are not likely involved in cellulose digestion (German and Bittong 2009); no conglomerations of microbes were observed with the SEM and TEM micro- graphs and microbial DNA concentrations are low $\left(<8 \mathrm{ng} \mu \mathrm{L}^{-1}\right)$ in the fishes' intestines (DPG, unpubl. data).

The dietary analyses showed that the wood-eating catfishes also consume a considerable amount (17-18\%) of amorphous detritus. However, $>70 \%$ of their intake appears to be wood detritus of varying sizes, with some diatoms $(6-8 \%)$ and algae (1-2\%) making up the difference. Clearly, wood is not the only material in these fishes' GI tracts, allowing detritus, either from the benthos, or that has collected in the interstitial spaces of decaying wood, to compose a sizeable portion of their daily intake. Given the propensity of these fishes to digest soluble polysaccharides 
and proteins (German and Bittong 2009), as seen in other detritivorous fishes (Smoot and Findlay 2000; Crossman et al. 2005), it makes sense that the fish would ingest items other than just wood, especially to meet nitrogen requirements. From a stable isotopic standpoint, the $\delta^{15} \mathrm{~N}$ signatures of the wood-eating catfishes' tissues $(>7.5 \%$ ) are too high to be coming solely from wood (1.3\%; German 2008). These data suggest that the catfishes supplement their wood diet with protein-rich detritus, or even some animal material to meet their nitrogen requirements. Although I did not observe animal material in the wood-eating catfish guts, Pt. disjunctivus did consume some animal material (including insects parts, molluscs, and worms), and all three species consumed detritus.

The longer guts in Pt. disjunctivus in comparison to the wood-eating taxa may have to do with the larger amount of inorganic material (i.e., sediment at $10 \%$ of total gut contents) consumed by the former. In marine systems, coralivorous fishes consume a large proportion of inorganic material in the form of carbonates, and have longer guts in comparison to other fishes (Elliott and Bellwood 2003), likely due to increased intake. Thus, because Pt. disjunctivus consumes more food of varying biochemical composition on a daily basis than the wood-eating fishes, which consume a consistent form of detritus that is $97 \%$ organic matter (Table 2), the former have longer guts and larger overall MVSA in their GI tracts.

The low wood fiber assimilation efficiencies in the catfishes are highly indicative that they cannot subsist on a wood only diet. Other xylivorous animals that have an active microbial community in their guts are capable of digesting the fibrous cell-wall fraction of wood (Breznak and Brune 1994; Felicetti et al. 2000; Karasov and Martínez del Rio 2007). For example, porcupines assimilate about $70 \%$ of NDF from wood with similar biochemical composition to that offered to the fish in this study (Felicetti et al. 2000). P. nigrolineatus and Pt. disjunctivus did clearly assimilate some cellulose from wood [given the small increase in the lignin:cellulose ratio (Abril and Bucher 2002) in the feces compared to the wood], and potentially some lignin, although the latter is likely an artifact of the detergent fiber analysis system (Jung 1997), which was designed for grasses (Goering and Van Soest 1970), not wood; lignin is considered indigestible by vertebrate animals (Karasov and Martínez del Rio 2007). The small change in the fecal lignin:cellulose ratio in the fish pales in comparison to the change in this ratio observed in termite feces (Karasov and Martínez del Rio 2007). Furthermore, the low OM digestibilities, and net loss of $\mathrm{N}$ combined with a loss of weight while eating wood further show that $P$. nigrolineatus and Pt. disjunctivus cannot thrive on a diet composed solely of wood. They clearly need to supplement their diet with detritus, or at least need detritus-laden wood, which we were not able to offer them in the laboratory. Individuals of Pt. disjunctivus likely did worse from weight and fecal nitrogen loss perspectives than individuals of $P$. nigrolineatus because the former lack the spoon-shaped teeth (Nelson et al. 1999) necessary to gouge wood in significant quantities (i.e., they had lower daily intake rates of wood). This is also supported by the observation that it took 6 weeks for Pt. disjunctivus to produce amounts of feces that P.nigrolineatus produced in 4 weeks.

In conclusion, the wood-eating catfishes in the family Loricariidae appear to be detritivores more so than true xylivores. They display none of the anatomical adaptations other xylivorous animals possess for the harboring of endosymbionts, and their digestive tracts are similar in shape and size to closely related detritivorous fishes. Furthermore, the fishes' whole digestive strategy ranging from intake, to passage rate, digestive enzyme activities, gastrointestinal fermentation, and decreasing surface area in the distal intestine suggests that these fishes are geared for the digestion and assimilation of soluble components of their detrital diet. However, the wood-eating catfishes do take macroscopic detritus (i.e., woody debris) and reduce it to $<1 \mathrm{~mm}$ in diameter, which likely has significant consequences for carbon cycling in their environment. Given that much of the Amazonian basin is unstudied, and much of it is under threat of deforestation (leading to more wood in waterways), the wood-eating catfishes may play a crucial role in the dynamics of the Amazonian ecosystem, and certainly in the reduction of coarse woody debris.

Acknowledgments I wish to thank David H. Evans, Karen A. Bjorndal, Douglas J. Levey, Larry M. Page, and Richard D. Miles for guidance and comments on an earlier form of this manuscript. Rosalie Bittong, Meaghan Callahan, Norma Lizardo, Robyn Monckton, Joseph Taylor, Daniel Neuberger, Ankita Patel, Alfred Thomson, Dieldrich Bermudez, Samantha Hilber, Nathan Lujan, Krista Capps, Don Taphorn, Alex Flecker, and David Werneke assisted with the collection, dissection, and/or processing of fishes and tissues. I thank the BarkerEmmerson family in Orlando, FL, for giving access to their land and private spring (Starbuck Spring). I am endebted to Kim Kelley and Kim Backer-Kelley in the UF EM laboratory for their endless help with my endeavors in electron microscopy. All handling of fish from capture to euthanasia was conducted under approved protocol D995 of the Institutional Animal Care and Use Committee of the University of Florida, which ensures that this study was conducted under the current laws of the United States of America. This project was funded by the University of Florida Mentoring Opportunity Program, National Science Foundation (NSF) GK-12 Research Stipend, an American Society of Ichthyologists and Herpetologists Raney Award, NSF grant DEB-0315963 (L.M. Page, PI), and NSF grant IOB-0519579 (D.H. Evans, PI).

Open Access This article is distributed under the terms of the Creative Commons Attribution Noncommercial License which permits any noncommercial use, distribution, and reproduction in any medium, provided the original author(s) and source are credited. 


\section{References}

Abramoff M, Magelhaes P, Ram S (2004) Image processing with ImageJ. Biophoton Int 11:36-42

Abril A, Bucher E (2002) Evidence that the fungus cultured by leafcutting ants does not metabolize cellulose. Ecol Lett 5:325-328

Ankom Technology (1998) Method for determining neutral detergent fiber (aNDF). Ankom Technical Manual, Fairport, NY

Ankom Technology (1999) Method for determining acid detergent fiber. Ankom Technical Manual, Fairport, NY

Araujo-Lima C, Forsberg B, Victoria R, Martinelli L (1986) Energy sources for detritivorous fishes in the Amazon. Science 234:1256-1258

Armbruster J (2003) The species of the Hypostomus cochliodon group (Siluriformes: Loricariidae) Zootaxa 249. Magnolia Press, Auckland

Armbruster J (2004) Phylogenetic relationships of the suckermouth armoured catfishes (Loricariidae) with emphasis on the Hypostominae and the Ancistrinae. Zool J Linn Soc 141:1-80

Bergman E (1990) Energy contributions of volatile fatty acids from the gastrointestinal tract in various species. Physiol Rev 70:567-590

Bouchard S, Bjorndal K (2006) Nonadditive interactions between animal and plant diet items in an omnivorous freshwater turtle Trachemys scripta. Comp Biochem Physiol B 144:77-85

Bowen SH (1984) Microorganisms and detritus in the diet of a typical neotropical riverine detritivore, Prochilodus platensis (Pisces: Prochilodontidae). Limnol Oceanogr 29:1120-1122

Bowen SH, Lutz EV, Ahlgren MO (1995) Dietary protein and energy as determinants of food quality: trophic strategies compared. Ecology 76:899-907

Breznak J, Brune A (1994) Role of microorganisms in the digestion of lignocellulose by termites. Ann Rev Entomol 39:453-487

Clements KD, Choat JH (1995) Fermentation in tropical marine herbivorous fishes. Physiol Biochem Zool 68:355-378

Clements KD, Raubenheimer D (2006) Feeding and nutrition. In: Evans DH (ed) The physiology of fishes. CRC Press, Boca Raton, FL, pp 47-82

Clements KD, Rees D (1998) Preservation of inherent contractility in isolated gut segments of herbivorous and carnivorous marine fish. J Comp Physiol B 168:61-72

Crossman DJ, Choat JH, Clements KD (2005) Nutritional ecology of nominally herbivorous fishes on coral reefs. Mar Ecol Progr Ser 296:129-142

de Melo CE, de Arruda Machado F, Pinto-Silva V (2004) Feeding habits of fish from a stream in the savanna of central Brazil, Araguaia Basin. Neotrop Ichthyol 2:37-44

Delariva R, Agostinho A (2001) Relationship between morphology and diets of six neotropical loricariids. J Fish Biol 58:832-847

Elliott JP, Bellwood DR (2003) Alimentary tract morphology and diet in three coral reef fish families. J Fish Biol 63:1598-1609

Felicetti L, Shipley L, Witmer G, Robbins CT (2000) Digestibility, nitrogen excretion, and mean retention time by North American porcupines (Erethizon dorsatum) consuming natural forages. Physiol Biochem Zool 73:772-780

Frierson E, Foltz J (1992) Comparison and estimation of absorptive intestinal surface area in two species of cichlid fish. Trans Am Fish Soc 121:517-523

Fris MB, Horn MH (1993) Effects of diets of different protein content on food consumption, gut retention, protein conversion, and growth of Cebidichthys violaceus (Girard), an herbivorous fish of temperate zone marine waters. J Exp Mar Biol Ecol 166:185-202

Galetto MJ, Bellwood DR (1994) Digestion of algae by Stegastes nigicans and Amphiprion akindynos (Pisces: Pomacentridae) with an evaluation of methods used in digestibility studies. J Fish Biol $44: 415-428$
German DP (2008) Beavers of the fish world: can wood-eating catfishes actually digest wood? A nutritional physiology approach. PhD dissertation. Zoology, University of Florida, Gainesville, FL

German DP (2009) Do herbivorous minnows have "plug-flow reactor" guts? Evidence from digestive enzyme activities, gastrointestinal fermentation, and luminal nutrient concentrations. J Comp Physiol B. doi:10.1007/s00360-009-0359-z

German DP, Bittong RA (2009) Digestive enzyme activities and gastrointestinal fermentation in wood-eating catfishes. J Comp Physiol B. doi:10.1007/s00360-009-0383-z

German DP, Horn MH (2006) Gut length and mass in herbivorous and carnivorous prickleback fishes (Teleostei: Stichaeidae): ontogenetic, dietary, and phylogenetic effects. Mar Biol 148:1123-1134

German DP, Nagle BC, Villeda JM, Ruiz AM, Thomson AW, Contreras-Balderas S, Evans DH (2009) Evolution of herbivory in a carnivorous clade of minnows (Teleostei: Cyprinidae): effects on gut size and digestive physiology. Physiol Biochem Zool (in press)

Goering HK, Van Soest P (1970) Forage fiber analyses (apparatus reagents, procedures and some applications). United States Department of Agriculture, Washington, DC

Hood JM, Vanni MJ, Flecker AS (2005) Nutrient recycling by two phosphorous-rich grazing catfish: the potential for phosphorouslimitation of fish growth. Oecologia 146:247-257

Horn MH (1989) Biology of marine herbivorous fishes. Oceanogr Mar Biol Ann Rev 27:167-272

Horn MH, Messer KS (1992) Fish guts as chemical reactors: a model for the alimentary canals of marine herbivorous fishes. Mar Biol 113:527-535

Horn MH, Gawlicka A, German DP, Logothetis EA, Cavanagh JW, Boyle KS (2006) Structure and function of the stomachless digestive system in three related species of New World silverside fishes (Atherinopsidae) representing herbivory, omnivory, and carnivory. Mar Biol 149:1237-1245

Jumars PA (2000) Animal guts as ideal chemical reactors: maximizing absorption rates. Am Nat 155:527-543

Jung HJG (1997) Analysis of forage fiber and cell walls in ruminant nutrition. J Nutr 127(Suppl):810S-813S

Karasov WH, Martínez del Rio C (2007) Physiological ecology: how animals process energy, nutrients and toxins. Princeton University Press, Princeton, NJ

Kramer DL, Bryant MJ (1995) Intestine length in the fishes of a tropical stream. 2. Relationships to diet-the long and the short of a convoluted issue. Environ Biol Fish 42:129-141

McDowell E, Trump B (1976) Histological fixatives for diagnostic light and electron microscopy. Arch Pathol Lab Med 100:405414

Moran KL, Bjorndal K (2007) Simulated green turtle grazing aVects nutrient composition of the seagrass Thalassia testudinum. Mar Biol 150:1083-1092

Mountfort D, Campbell J, Clements KD (2002) Hindgut fermentation in three species of marine herbivorous fish. Appl Environ Microbiol 68:1374-1380

Nelson JA, Wubah D, Whitmer M, Johnson E, Stewart D (1999) Wood-eating catfishes of the genus Panaque: gut microflora and cellulolytic enzyme activities. J Fish Biol 54:1069-1082

Nico LG (2005) Changes in the fish fauna of the Kissimmee River basin, penninsular Florida: non-native additions. In: Rinne JN, Hughes RM, Calamusso B (eds) Historical changes in large river fish assemblages of the Americas. American Fisheries Society, Bethesda, MD, pp 523-556

Nico LG, Jelks HL, Tuten T (2009) Non-native suckermouth armored catfishes in Florida: description of nest burrows and burrow colonies with assessment of shoreline conditions. Aquat Nuis Spec Res Progr Bull 1:1-30 
Novakowski GC, Hahn NS, Fugi R (2008) Diet seasonality and food overlap of the fish assemblage in a pantanal pond. Neotrop Ichthyol 6:567-576

Penry DL, Jumars PA (1987) Modeling animal guts as chemical reactors. Am Nat 129:69-96

Pouilly M, Lino F, Bretenoux J, Rosales C (2003) Dietary-morphological relationships in a fish assemblage of the Bolivian Amazonian floodplain. J Fish Biol 62:1137-1158

Presnell JK, Schreibman MP (1997) Humason's animal tissue techniques. The Johns Hopkins University Press, Baltimore, MD

Prins RA, Kreulen DA (1991) Comparative aspects of plant cell wall digestion in insects. Anim Feed Sci Technol 32:101-118

Pryor GS, Bjorndal K (2005) Symbiotic fermentation, digesta passage, and gastrointestinal morphology in bullfrog tadpoles (Rana catesbeiana). Physiol Biochem Zool 78:201-215

Pryor GS, German DP, Bjorndal K (2006) Gastrointestinal fermentation in Greater Sirens (Siren lacertina). J Herpetol 40:112-117

Salvador LF, Salvador GN, Santos GB (2008) Morphology of the digestive tract and feeding habits of Loricaria lentiginosa Isbrücker, 1979 in a Brazilian reservoir. Act Zool 90:101-109

Schaefer S, Stewart D (1993) Systematics of the Panaque dentex species group (Siluriformes: Loricariidae), wood-eating armored catfishes from Tropical South America. Ichthyol Explor Freshwat 4:309-342

Smith T, Wahl D, Mackie R (1996) Volatile fatty acids and anaerobic fermentation in temperate piscivorous and omnivorous freshwater fish. J Fish Biol 48:829-841

Smoot JC, Findlay RH (2000) Digestive enzyme and gut surfactant activity of detrivorous gizzard shad (Dorosoma cepedianum). Can J Fish Aquat Sci 57:1113-1119

Stevens CE, Hume ID (1998) Contributions of microbes in vertebrate gastrointestinal tract to production and conservation of nutrients. Physiol Rev 78:393-427

Vispo C, Hume ID (1995) The digestive tract and digestive function in the North American porcupine and beaver. Can J Zool 73:967974

Xu PE, Distel DL (2004) Purification and characterization of an endo-1,4- $\beta$-D glucanase from the cellulolytic system of the wood-boring marine mollusk Lyrodus pedicellatus (Bivalvia: Teredinidae). Mar Biol 144:947-953

Zihler F (1982) Gross morphology and configuration of digestive tracts of Cichlidae (Teleostei: Perciformes): phylogenetic and functional significance. Neth J Zool 32:544-571 